\title{
https://doi.org/10.48009/2_iis_2006_241-245 \\ INFORMATION TECHNOLOGY ADDRESSES TRANSPARENCY: THE POTENTIAL EFFECTS OF XBRL ON FINANCIAL DISCLOSURE
}

\author{
Yuan Li, The University of Texas Pan American, yli1@utpa.edu \\ Joseph N. Roge', The University of Texas Pan American, jroge@ panam.edu \\ Les Rydl, The University of Texas Pan American, Irydl@ panam.edu \\ Mike Crews, The University of Texas Pan American, rcrews@panam.edu
}

\begin{abstract}
eXtensible Business Reporting Language (XBRL) may vastly improve the transparency of firms' financial information. Financial statements in XBRL format allow financial report users to directly search for relevant information regardless of the location of the information and to easily compare related information between different companies. As a consequence, management's financial reporting choices and financial disclosure management practices are more explicitly presented to users.
\end{abstract}

Keywords: XBRL (Extensible Business Reporting Language), GAAP (Generally Accepted Accounting Principles), Transparency, Financial Reporting

\section{INTRODUCTION}

The anticipated clarity expected to accrue to users of financial statements, along with any increased efficiencies of resource allocation to firms by investors, are expected, in turn, to affect management's financial reporting system choices and disclosure management practices. In theory, the result of this process should be an equilibrium in which transparency and investor resource allocation efficiencies are optimized over time.

Therefore, as XBRL becomes more widely accepted, its impact on management's decisions relative to financial disclosure, user's reactions relative to resource allocations to firms, and management's reactions to user investment decisions are issues to be addressed. These and other issues for future research are identified and discussed.

\section{FINANCIAL DISCLOSURE}

Early research on the management of corporate financial disclosure has provided evidence suggesting that managers may provide financial information for various reasons. While Gibbins [10] sees disclosures, in general, as any deliberate release of financial information, Stoken [24] defines disclosure management in terms of the strategic manipulation of financial information that the firm's reporting system generates.

Therefore, manager's motivations to disclose include, but are not limited to, efforts to enhance their firms' value [25] and attempts to protect proprietary information that may be used to their own personal advantage [6]. Such disclosures may occur through manipulation of financial reports and may be linked to manager's choices of financial reporting systems [24]. Here, financial reporting system choices are determinates of the precision of a firm's set of accounting policies and procedures [24].

Of course, disclosure is not a substitute for proper accounting and may prove to be deceptive [11]. Consider, for example, that cash basis accounting for the cost of goods sold is misleading, even if accrual basis amounts are disclosed in the notes to the financial statements. The notes to financial statements generally amplify or explain the items presented in the main body of the statements. Also, supplementary information may include details that present a different perspective from that of the financial statements. Regardless, financial statements are generally accepted as a formalized, structured way of exchanging financial information. And, as such, the items on financial statements should meet the definition of a basic element in a conceptual framework [20]. They should also be measurable with sufficient certainty, and be relevant and reliable.

In addition, financial reports must comply with generally accepted accounting principles (GAAP) and are monitored by the Securities Exchange Commission (SEC). Since these reports are intended to help investors and creditors with capital allocation decisions related to the reporting companies, the accounting principles that support them must be regulated by an acceptable authority. However, regulatory efforts may result in financial reports becoming more complex and therefore, less transparent, over time [15].

A lack of transparency tends toward less useful information that, in turn, may produce increased 
levels of uncertainty among financial statement users. When combined with the potential for management manipulation of disclosure information, users of financial reports are likely to face increased levels of risk. Therefore, while antifraud laws, audits, and costly signals may deter false claims [18], a resulting lack of transparency in financial reporting may be problematic to users of the information presented in some organizational releases.

\section{TRANSPARENCY}

Due to such lacks of transparency, users of financial data have generally realized that a reliance on current company reporting systems and a focus on earnings have resulted in higher risks in the market as managers attempt to manage earnings [1]. More specifically, they are finding that reported quarterly earnings may be suspect. As transparency decreases, these and other financial data are not always seen as reflecting the long term profitability of a firm. Consequently, those who lack access to financial data and expertise in ferreting out financial information tend to be less knowledgeable of the fair value of financial instruments [8].

As a result, users are beginning to differentiate between companies based on the efficiency with which they communicate shareholder value. In response to their perceived lack of transparency, they seek detailed information on company assets [21]. They also appear ready to reward companies that increase the level of transparency associated with their financial reporting [22]. In doing so, users are expressing a need for information from companies that is enhanced and accessible [13].

While firms will tend to respond to these expressed needs, organizational attempts to balance internal needs and external transparency demands will likely persist [2]. On the one hand, firms with lower expected earnings may decrease transparency to maintain their stock prices [19]; on the other hand, investors will reward higher transparency in order to meet the demand of their investors [14]. While less transparency is more likely to enable managers to hide accounting problems and provide self-interested reporting of their financial data [9], greater transparency in reporting formats is more likely to reduce the management of earnings [19]. However, companies attempting "to give the market what it wants" will tend to move toward transparency and companies with business models that incorporate built in inefficiencies are likely to avoid doing so [21].
Recent financial reporting scandals offer support to this position, and, as a result, regulating agencies around the world are moving toward standardization of financial reporting. But as international companies look at the different financial reporting standards in one country vs. another, the task of presenting shareholder value seems daunting if not impossible. In the U. S. the SEC is promoting US GAAP (US Generally Agreed Accounting Principals) as the standard while the EU Community is standing by IAS (International Accounting Standards). International companies will have to adopt reporting standards in their accounting software which will allow flexible report writing capabilities [5]. Of course, such software is one element of financial reporting system choice.

\section{FINANCIAL REPORTING SYSTEM CHOICE}

However, further confounding the situation, are suggestions that management's decision to manipulate financial reports are tightly bound to financial reporting system choices [23, 17, 24]. Here we recall that financial disclosure management has been discussed in terms of strategic manipulation of financial information generated by the firm's reporting system and financial reporting system choice in terms of the resulting precision of accounting policies and procedures [24].

Consider Stocken's [24] findings. When a manager strategically manipulates financial information to artificially improve the firm's economic performance, the manager tends to prefer a nontransparent financial statement. However, when a manager has some private information that is not captured by the firm's financial reporting system and may be at risk to manipulate the financial report, the manager may not choose the most precise financial reporting system.

Stocken concludes that, in general, if a firm chooses an accounting policy or procedure that inadequately captures the firm's economic performance for a period, the firm's financial system generates less precise financial information.

\section{MANAGING FINANCIAL DISCLOSURES}

Managerial manipulation of financial reports may also be problematic. As discussed earlier, financial disclosure management may involve the strategic manipulation of financial information generated by a firm's reporting system [24]. Such disclosures include both disclosure and exclusion of financial information and are related to economic incentives 
that exist [10]. However, from the point of view of financial information users, the existence of organizational mechanisms that promote desirable disclosures while discouraging undesirable disclosures may provide positive benefits; in other words, not all disclosure management may be bad [2].

For example, Gibbins [10] found that in regulated markets, the public has access to information on capital allocation processes that ultimately determine the firm's profitability. In their interview data, they found that there was a general aversion to selfpromotion but also a clear desire to keep the firm in the public eye with sufficient information on the firm's financial position so as to ensure access to capital markets.

Managers concerned about the effect of financial disclosure on their competitive positions were careful not to "give too much away." Therefore, we suggest that both financial disclosure management and financial reporting system choice are related to transparency issues. Such issues include, but are not limited to, the investment efficiencies of the users of financial disclosure information via investor allocation of resources between firms.

Consequently, the above discussion, taken in its entirety, leads us to suggest that information technology, via XBRL may provide an effective and efficient tool for users of financial disclosure information to deal with such issues.

\section{XBRL}

XBRL, a member of the family of languages based on XML, or Extensible Markup Language, is becoming a standard for the electronic exchange of data between businesses on the Internet. Using XML, identifying tags are attached to items of data so they can be processed efficiently by computer software. Therefore, XML has gained wide acceptance throughout the information technology community as a primary method to provide efficient data communication over the Internet [3]. As an XML convention, XBRL is easily extensible and can be used across platforms, software formats, and/or technologies. These XBRL characteristics allow the complex, ever-changing financial reporting process to become more efficient and economical. As a result, it is becoming increasingly popular in public financial reporting.

Within XBRL documents, each financial item is assigned a unique, predefined data tag. These tags are established according to financial accounting standards. Using these tags, every data element is fully described in terms of its definition, format, location, calculation, and labeling. The tags themselves act like barcodes that stick to data regardless of their paths, destinations, or usages. XBRL can show how items are related to one another and can also identify whether they fall into particular groupings for organizational or presentational purposes. Users of financial reports do not see the embedded tags when they retrieve financial information, but the tags contain important facts regarding the meaning and the location of the information. When financial statement users search XBRL-formatted documents, all related information within financial reports can be presented to users simultaneously.

XBRL provides many benefits for both financial report users and producers. Its data tags are computer readable and allow automated processing of business information by computer software. This eliminates laborious and costly processes associated with manual re-entry and comparison. Computers can also treat XBRL tagged data "intelligently"; they can recognize the information in XBRL documents, allowing the processes of information selection, analysis, storage, presentation, and exchange with other computers to be automated. Therefore, XBRL greatly increases the speed of handling financial data and reduces the chance of error. It offers cost savings, greater efficiency, and improved accuracy and reliability to all involved in supplying and using financial information.

To users of financial statements, XBRL reduces the research costs associated with investments. Developing financial models and comparing performance and solvency become simpler processes when using XBRL documents. More importantly, data tags enable financial report users to more easily recognize management financial reporting choices. As a result, increased transparency provides more useful information and uncertainty decreases. Accordingly, users are better able to evaluate the reliability of corporate managers' fair value determinations. User investment decisions become more firmly supported by their evaluation of the quality of financial reports and their understanding of the financial information disclosed within them.

To companies supplying financial statements, XBRL provides major benefits in the preparation, analysis, and exchange of business information. As business information and financial data flows from original business transactions to corporate headquarters and 
on to government regulatory agencies and other thirdpart stakeholders, data passes through a multitude of transcriptions, manipulations and software conversions. With XBRL, financial information and supporting text from internal systems can be expressed in a single specification, which in turn can be used continuously throughout the process. Consequently, the information required by the SEC, the IRS, and for publishing via the Web can be automated.

In addition, XBRL increases a company's information visibility and accessibility to the capital market. According to a Thomson Financial report, 29 percent of U.S. companies listed on NASDAQ and 16 percent listed on the New York Stock Exchange have no research coverage. Making information available in an industry-standard format that is easily received, analyzed, and evaluated may also increase a company's likelihood of being tracked by financial analysts and its chances of attracting additional investment capital.

\section{POTENTIAL EFFECTS}

As XBRL continues to emerge, users of financial report information have indicated a strong interest in its application. Some researchers suggested that, in addition to potential affects on user acquisition and processing of financial information, XBRL might further influence user judgments and decisions based on the information obtained [7, 12]. Hodge [16] conducted an investigation in the context of recognition versus disclosure of stock option compensation. They investigated whether using an XBRL-facilitating technology improved nonprofessional investors' acquisition and integration of financial information in investment decisions. Their findings suggested that when stock option accounting varies between two firms, search technology helps users to both acquire and integrate relevant information. In their experiment, participants who used XBRL-facilitating technology were more likely to acquire footnote information. They were also more likely to integrate the footnote information with related information on the face of the income statement when making judgments and decisions. When compared to participants who did not, differences in investment decisions were detected.

Based on their results, Hodge [16] concluded that the implementation of XBRL improves the transparency of a firm's financial statement information and managers' choices for reporting that information. They also suggested a link between searchfacilitating technology and managerial decisions with respect to financial reporting. As a result, they predicted that the "effect of XBRL on users' decisions may mitigate the benefits of managers lobbying for and choosing financial reporting approaches that "artificially" enhance the financial performance or condition of the firm".

We find their suggestion of an XBRL effect on management's financial reporting system choices very interesting and attractive. As XBRL increases the transparency of financial reports in general and managers' financial reporting system choices and disclosure management efforts in particular, the disclosure reputation of firms along with users interpretation of the quality of financial information presented will be enhanced.

Therefore, as XBRL increases the transparency of management's financial reporting choices and disclosure management to the uses of financial information, the reliability and the reputation of their financial information will be more easily analyzed and evaluated. Consequentially, as the adoption of $\mathrm{XBRL}$ to support financial reporting process becomes more common, managers may become aware that their capital market positions are being affected. Therefore, their attitudes and decisions concerning financial reporting system choices and financial disclosure management may change.

If managers realize that disclosure management may damage firms' reputation and affect users' investment decision after XBRL adoption, they will become more likely to choose more precise or neutral accounting policies and procedures on their financial reporting. Similarly, if managers realize that XBRL adoption makes their financial disclosure management transparent, they will become less likely to engage in financial disclosure management that is harmful to the users of financial reports.

\section{REFERENCES}

1. Allen, M. F. \& Cote, J. (2005). Creditors' Use of Operating Cash Flows: An Experimental Study. Journal of Managerial Issues, 1I7(2), 198-211.

2. Anil, A; Glover, J. C.; \& Sunder, S. (2003). Are Unmanaged Earnings Always Better for Shareholders? Accounting Horizons, 17, 11-116.

3. Bergeron, B. P. (2003). Essentials of XBRL: financial reporting in the $21^{\text {st }}$ century. Hoboken, N.J. John Wiley \& Sons, Inc.

4. Cheney, G. (2005). XBRL A technology whose time is now. Financial Executive. March: 45-47.

5. Coffin, Z. (2002). The Top Ten Effects of XBRL: The Future of Internet Reporting. Extract 
from Introducing XBRL: Making Decisions in a Digital Economy.

6. Dye, R. A. (1985). Disclosure of nonproprietary information. Journal of Accounting Research, 23(1), 123-145.

7. Eccles, R.; Herz R.; Keegan E.; \& Phillips D. (2001). The ValueReporting ${ }^{T M}$ Revolution. New York: John Wiley \& Sons, Inc.

8. Evans, M. (2005). Should bond markets be more transparent. International Financial Law Review, 24(10), 6-6.

9. Fan, J. P. H. \& Wong, T. J. (2002). Corporate ownership structure and the informativeness of accounting earnings in East Asia. Journal of Accounting \& Economics, 33(3), 401.

10. Gibbins, M.; Richardson A.; \& Waterhouse, J. (1990). The management of corporate financial disclosure: opportunism, ritualism, policies, and processes. Journal of Accounting Research, 28(1), 121-143.

11. Hake, E. R. (2005). Financial Illusion: Accounting for Profits in an Enron World. Journal Of Economic Issues, 34(3), 595-611.

12. Hannon, N. (2002). Accounting scandals: Can XBRL help? Strategic Finance. August, 61-62.

13. Harrington, C. (2005). The accounting profession: looking ahead: some key leaders identify the current initiatives that will shape developments. Journal of Accountancy, 200(4), 43-45, 47-48.

14. Hebb, T. (2006). The Economic Inefficiency of Secrecy: Pension Fund Investors' Corporate Transparency Concerns. Journal of Business Ethics, 63(4), 385-405.

15. Heffes, E. M. (2005). FASB Chairman Robert Herz: Complexity Impedes Transparency, Financial Executive. November, 16-20.
16. Hodge, F.; Kennedy J.; \& Maines, L. (2004). Does search-facilitating technology improve the transparency of financial reporting? The Accounting Review, 79(3), 687-703.

17. Holthausen, R. W. (1990). Accounting method choice: Opportunistic behavior, efficient contracting and information perspectives. Journal of Accounting and Economics, 12(1-3), 207-218.

18. Hughes, P.J. (1986). Signaling by direct disclosure under asymmetric information. Journal of Accounting and Economics, 8(4-6), 136.

19. Hunton, J. E.; Libby, R., \& Mazza, C. L. (2006). Financial Reporting Transparency and Earnings Management. Accounting Review, 81(1), 135157.

20. Kieso, D.; Weygandt, J.; Warfield, T. (2004). Intermediate accounting. John Wiley and Sons, Inc.

21. Phillips, D. (2000). Value reporting - Giving the market what it wants. Accountancy Age. Nov. 8.

22. Schipper, K. (1989). Commentary on earnings management. Accounting Horizons, 3(4), 91102.

23. Robinson, D. \& Burton, D. (2004). Discretion in Financial Reporting: The Voluntary Adoption of Fair Value Accounting for Employee Stock Options. Accounting Horizons, 18(2), 97-108.

24. Stocken, P. \& Verrecchia R. (2004). Financial reporting system choice and disclosure management. The Accounting Review, 79(4), 1181-1203.

25. Verrecchia, R.E. (1983). Discretionary disclosure. Journal of Accounting and Economics, 5(10-12), 179-194. 